\title{
UNIVERSITYOF
}

FORWARD

THINKING

WESTMINSTER用

WestminsterResearch

http://www.westminster.ac.uk/westminsterresearch

Community Spirit? Haunting Secrets and Displaced Selves in Contemporary Scottish Fiction

Germanà, $\mathbf{M}$.

This is a pre-publication version of a book chapter to be published in Germanà, M. (2016) Community Spirit? Haunting Secrets and Displaced Selves in Contemporary Scottish Fiction in: Lyall, S. (ed.) Community in Modern Scottish Literature Leiden Brill pp. 235-253 9789004317444

The WestminsterResearch online digital archive at the University of Westminster aims to make the research output of the University available to a wider audience. Copyright and Moral Rights remain with the authors and/or copyright owners.

Whilst further distribution of specific materials from within this archive is forbidden, you may freely distribute the URL of WestminsterResearch: ((http://westminsterresearch.wmin.ac.uk/).

In case of abuse or copyright appearing without permission e-mail repository@westminster.ac.uk 


\section{Community Spirit? Haunting Secrets and Displaced Selves in Contemporary Scottish Fiction}

\section{Monica Germanà}

ABSTRACT: Framed by the disquieting coalescence of the unfamiliar within the familiar, described by Sigmund Freud in his study of the 'uncanny', and later developed by Homi K. Bhabha and Julia Kristeva with specific references to the 'strangers' of our communities, this essay deploys this theoretical basis to highlight the problematic representation of community within contemporary Scottish writing. What emerges in the two representative works that this essay analyses in detail Louise Welsh's The Cutting Room (2002) and John Burnside's The Devil's Footprints (2007) - is a deep interrogation of the self/other binary opposition with regard to identity/community construction. Rather than the collective knowledge of shared values and traditions, what binds these 'imagined communities', is a spectral web of secrets and the shared awareness of human corruption.

Although community and common values may be seen to have traditionally underpinned Scottish politics and culture, in the twenty-first century, when 'glocal'" has replaced global, community has developed into an increasingly problematic political concept. In fact, at the end of the twentieth century, community was already looked upon with a degree of suspicion, when Anthony Cohen suggested that "“[c]ommunity" is one of those words - like "culture", "myth", "ritual”, "symbol”bandied around in ordinary, everyday speech, apparently readily intelligible to speaker and listener, which, when imported into the discourse of social science ... causes immense difficulty'. ${ }^{2}$ That the postmodern demise of grand narratives registered in the second half of the twentieth century may have exacerbated the notions of disorientation and dislocation that characterise the politics of postcolonial/postmodern identity seems hardly surprising. As Jonathan Rutherford notes, too, there

\footnotetext{
${ }^{1}$ See S. M Miller, Recapitalizing America: Alternatives to the Corporate Distortion of National Policy (Boston: Routledge and Kegan Paul, 1981), p. 180.

${ }^{2}$ A. P. Cohen, The Symbolic Construction of Community (London and New York: Routledge, 1985), p. 11.
} 
is a sense in which "[i]n this postmodern, "wide-open" world our bodies are bereft of those spatial and temporal co-ordinates essential for historicity, for a consciousness of our own collective and personal past' and that '[o]ur struggles for identity and a sense of personal coherence and intelligibility are centred on this threshold between interior and exterior, between self and other'. ${ }^{3}$ Significantly, what both Rutherford and Cohen draw attention to is the positioning of demarcating lines, 'thresholds' or 'boundaries', which serve to define those who belong in communities in the name of their intrinsic homogeneity, or sameness, vis-à-vis the others, those who, by virtue of their difference, do not belong to such communities. Yet, as Cohen further illustrates, the nature of such boundaries is largely symbolic, and, in turn, communities are the by-product of the complex intersection of emotional, political and social factors. Discussing the case of Scottish devolution, and, in particular, the first referendum campaign in the late 1970s, Cohen argues that the political argument went beyond the pros and cons of devolution, to interrogate the foundations of Scottish national identity in much more fundamental terms:

The question became not simply, 'Are the Scots different from the English?', but, 'How different am I, as a particular Scot, from him, another particular Scot?' In other words, is the boundary dividing Scotland from England more meaningful to the highlander than those which distinguish him from the lowlander, the Glaswegian from the Edinburghian; the Shetlander from the Orcadian; the inhabitants of one Shetland island from those of another; the members of one township of a Shetland island from the members of another. ${ }^{4}$

What Cohen's influential study emphasises is the interrelationship between community and identity particularly in reference to the individual desire to belong to a collective group. As Gerard Delanty suggests, following Cohen, 'the term community does in fact designate both an idea about

\footnotetext{
${ }^{3}$ Jonathan Rutherford, 'A Place Called Home: Identity and the Cultural Politics of Difference', in Identity: Community, Culture, Difference, ed. by Jonathan Rutherford (London: Lawrence \& Wishart, 1990), pp. 9-27 (p. 24; emphases added).

${ }^{4}$ Cohen, The Symbolic Construction of Community, p. 13.
} 
belonging and a particular social phenomenon, such as expressions of longing for community, the search for meaning and solidarity, and collective identities'. ${ }^{5}$ The slipperiness of the term, and especially the relationship between community and identity, become increasingly harder to pin down in the twenty-first century cosmopolitan context of globalised markets and postcolonial diasporic migrations, where the concept of community remains ambiguous; as Delanty argues:

[1]ying at the heart of the idea of community is an ambivalence. On the one side, it expresses locality and particularness - the domain of immediate social relations, the familiar, proximity - and, on the other, it refers to the universal community in which all human beings participate. ${ }^{6}$

This essay explores the problematic representation of community in two examples of postdevolution Scottish fiction: Louise Welsh's The Cutting Room (2002) and John Burnside's The Devil's Footprints (2007). The investigation highlights the challenging exposure of the clash between collective identity and individual desire, resulting in the representation of uncanny communities simultaneously haunted by the presence of troubling secrets and the apparent threat of outsiders. This is a theme already foreshadowed in the late-twentieth-century literary production of the so-called second Scottish Renaissance: the societies represented in the works of James Kelman (such as The Busconductor Hines [1984] and A Chancer [1985]), Iain Banks (The Wasp Factory [1984]), Janice Galloway (The Trick is To Keep Breathing [1989] and Blood [1992]), A. L. Kennedy (Looking for the Possible Dance [1993] and So I Am Glad [1995]), as well as in the (post)apocalyptic fictions of Alasdair Gray's Lanark (1981) Margaret Elphinstone's The Incomer (1987) and A Sparrow's Flight (1989), and Alan Warner's These Demented Lands (1997) display a distinct lack of coherent community. The winning of devolution in 1997 and the establishment of the Scottish Parliament in 1999 would not appear to have assuaged the inner tensions of Scottish

\footnotetext{
${ }^{5}$ Gerard Delanty, Community (London and New York: Routledge, 2003), p. 3.

${ }^{6}$ Delanty, Community, p. 12.
} 
communities. What in fact emerges in the more recent works which this essay analyses is an intense interrogation of the self/other, us/them binarisms, pointing to wider questions about the so-called 'community spirit' against the glocal context in which these novels are situated.

What binds together these 'imagined communities', then, rather than the collective knowledge of shared values and traditions, is the spectral web of secrets that may undermine any stable reading of 'community spirit'. For Benedict Anderson the nation 'is an imagined political community - and imagined as both inherently limited and sovereign', and he goes on: '[i]t is imagined because the members of even the smallest nation will never know most of their fellowmembers, meet them, or even hear of them, yet in the minds of each lives the image of their communion'. ${ }^{7}$ There are several problems with Anderson's conceptualisation of 'imagined community', and many subsequent critics have offered critical rejoinders to Anderson's study. Homi Bhabha responds to Anderson's theory emphasising the liminal quality of the 'image' conjured up by Anderson's 'imagined community' ${ }^{8}$ Bhabha's argument reads the nation not in the terms of cultural uniformity and shared consensus implied in Anderson's argument, but rather as the complex and composite site of the tensions and dissonances generated by a nation's 'conceptual indeterminacy':

If the ambivalent figure of the nation is a problem of its transitional history, its conceptual indeterminacy, its wavering between vocabularies, then what effect does this have on narratives and discourses that signify a sense of 'nationness': the heimlich pleasures of the hearth, the unheimlich terror of the space or race of the Other; the comfort of social belonging, the hidden injuries of class; the customs of taste, the powers of political affiliation; the sense of social order, the sensibility of sexuality; the blindness of

\footnotetext{
${ }^{7}$ Benedict Anderson, Imagined Communities: Reflections on the Origin and Spread of Nationalism (London and New York: Verso, 1991), p. 6.

${ }^{8}$ Homi K. Bhabha, 'Introduction: Narrating the Nation', in Nation and Narration, ed. by Homi K. Bhabha (London: Routledge, 1990), pp. 1-7 (p. 1).
} 
bureaucracy, the straight insight of institutions; the quality of justice, the common sense of injustice; the langue of the law and the parole of the people. ${ }^{9}$

In his juxtaposition of 'the heimlich pleasures of the hearth' to 'the unheimlich terror of the space or race of the Other', it is significant that Bhabha uses the language of the Gothic uncanny to challenge the monologic coherence of nation as 'imagined community'. Sigmund Freud famously drew attention to the ambiguous semantics of unheimlich (uncanny), pointing to the coalescence of the familiar and the unfamiliar within the same term. Repeating the words of Schelling, Freud claims that 'the term 'uncanny' [...] applies to everything that was intended to remain secret, hidden away, and has come into the open' ${ }^{10}$ Thus uncanny refers to that which is homely, known and familiar, and simultaneously, foreign, mysterious and unfamiliar. As David Punter comments, '[t]his remains the crucial point in the definition of the uncanny: namely, that it represents a feeling which relates to a dialectic between that which is known and which is unknown'. ${ }^{11}$ It is, however, the notion of 'familiarity' that, implicit as it is in the notion of the uncanny, raises questions about familiar bonds and kinship. As Andrew Bennett and Nicholas Royle rightly suggest:

The uncanny is not just a matter of the weird or spooky, but has to do more specifically with a disturbance of the familiar. Such a disturbance might be hinted at by way of the word 'familiar' itself. 'Familiar' goes back to the Latin familia, a family: we all have some sense of how odd families can seem (whether or not one is 'part of the family'). The idea of 'keeping things in the family' or of something that 'runs in the family', for instance, is at once familiar and potentially secretive or strange. ${ }^{12}$

\footnotetext{
${ }^{9}$ Bhabha, 'Introduction: Narrating the Nation', p. 2.

${ }^{10}$ See Sigmund Freud, The Uncanny [1919], ed. by Hugh Haughton, trans. By David McLintock (London: Penguin, 2003), p. 132.

${ }^{11}$ David Punter, 'The Uncanny', in The Routledge Companion to Gothic, ed. by Catherine Spooner and Emma McEvoy (London and New York: Routledge, 2007), pp. 129-136 (p. 130).

${ }^{12}$ Andrew Bennett and Nicholas Royle, An Introduction to Literature, Criticism and Theory (Harlow: Pearson, 2004), p. 34 .
} 
In using the term 'unheimlich' to refer to the threat of the other, Bhabha unveils the darker side of what we might call community. Haunting a collective of people with seemingly shared values and interests at heart is the unhomely side of the uncanny: that which does not sit comfortably within the boundaries set by the community; that which deviates from the norm; that which cannot be understood or even spoken about.

It is this 'mysterious' quality of community that Zygmunt Bauman relates to in his response to Anderson's theorisation of community. Moving away from its original association to 'nation', and focusing instead on the definition of community itself, Bauman reflects on the inexplicable bonds within a community of strangers:

Benedict Anderson coined the term 'imagined community' to account for the mystery of self-identification with a large category of unknown strangers with whom one believes oneself to share something important enough to make one speak of them as 'we' of which I, the speaker, am a part. ${ }^{13}$

Bauman finds the roots of Anderson's argument in 'the disintegration of impersonal ties and bonds' which defined the culture of the late-twentieth century in terms of the "closeness, intimacy, "sincerity", "turning oneself inside out", holding no secrets, compulsive and compulsory confessing [that] were fast becoming the sole human defences against loneliness and the sole yarn available to weave the craved-for togetherness'.${ }^{14}$ Within this open, transparent community framework, 'sameness' becomes erroneously associated with ‘identity', and, consequently, an arguably misguided sense of belonging.

\footnotetext{
${ }^{13}$ Zygmunt Bauman, Liquid Love: On the Frailty of Human Love (Cambridge: Polity, 2003), p. 32.

${ }^{14}$ Bauman, Liquid Love, p. 32.
} 
The two novels analysed in this chapter interrogate the notion of community, emphasising the coexistence of the 'unhomely', 'unfamiliar', and 'deviant' next to the 'homely', 'familiar', and 'normal'. In this way, the novels revolve around the strange stories buried under the surface of apparently familiar settings, and unveil the unsettling geographies of uncanny communities. What links the collective groups of Welsh's The Cutting Room and Burnside's The Devil's Footsteps is not a set of shared values and beliefs, nor the 'easy' sense of belonging within the imagined thresholds of each community; rather, what distinguishes the uncanny communities of the two novels is the presence of secretive knowledge which haunts the individual members of the community. Such secrets, whilst creating a profound sense of division, and distrust of the other(s), also, paradoxically, bind the community together, hinting to a less manifest, but nevertheless, 'real' community spirit based on an increased empathy towards the other.

Set in Glasgow, The Cutting Room is a literary crime novel plotted around a collection of disturbing pornographic images found by Rilke, an auctioneer, as part of the estate of the recently deceased Roddy McKindless. The images - part of a set of a sadistic snuff photo-shoot at the end of which the female model is apparently murdered - send Rilke on a trail for clues about their authenticity, a disturbing treasure hunt partly motivated by Rilke's untold troubled past; as Lesley McDowell notes in her review of the novel: 'The girl in the pictures has perplexed and frightened him. His ramshackle investigation into her decades-old murder is an attempt to make amends; Rilke feels implicated somehow in the world that exploited and wasted the girl'. ${ }^{15}$ The implied reference to Rilke's past echoes the overarching use of Gothic conventions which make The Cutting Room a hybrid crime novel; while exposing Glasgow's demi-monde, Welsh self-consciously deploys many of Glasgow's Gothic settings - the University cloisters, the Royal Infirmary, and the Necropolis, 'Glasgow’s first "hygienic cemetery”, established in the early nineteenth century, designed to avoid the spread of cholera and a slippage of corpses from ill-dug graves, which had become a city

\footnotetext{
${ }^{15}$ Lesley McDowell, 'The Cutting Room by Louise Welsh: The literary beauty of a Glaswegian beast', The Independent, 9 August $2002<\mathrm{http}$ ///www.independent.co.uk/arts-entertainment/books/reviews/the-cutting-room-bylouise-welsh-639353.html> [accessed 17 September 2014].
} 
scandal'. ${ }^{16}$ Links to the Gothic exist also in the form of important literary references to Scottish Gothic texts such as James Hogg's The Private Memoirs and Confessions of a Justified Sinner (1824) - we are told, for instance, that pub owner Victor Gilmartin is a 'man under whose tarmacadamed roads are reputed to lie not a few bodies' - and Robert Louis Stevenson's Strange Case of Dr Jekyll and Mr Hyde (1886), which is referenced in one of the novel's epigraphs and in the name of Steenie (Steven) Stevenson. ${ }^{17}$ With these canonical doppelgänger narratives The Cutting Room also shares the duality which pervades the novel's main characters: first and foremost, the villain, Roddy McKindless, is presented as the perfect legacy of Dr Jekyll and Mr Hyde, a distinguished gentleman with a dark fetish for voyeurism and torture. But beside him, the remaining characters all partake in the moral ambiguities of Hogg's and Stevenson's anti-heroes: as part of their business, both Rilke and his employer, Rose Bowery, are enmeshed in the corrupt world of antique dealing; even the integrity of Anderson, the policeman, is tainted by virtue of his friendship with Rilke and, most importantly, his liaison with Rose: 'She'll get me into trouble', he admits towards the end of the novel, 'if I'm not careful' ${ }^{18}$ Welsh's deliberate flirtations with the Scottish Gothic predecessors function to establish a sense of endemic corruption: just as in Stevenson's novella, where all the main characters are in some way linked to Hyde, so do all the characters in The Cutting Room share a network of relationships, which make them all complicit in the endemic corruption that qualifies Glasgow as a community.

Damaged to the core, Glasgow is a city haunted by its own past. Driving through the city, Rilke wonders, for instance, 'if any suicides were buried beneath these crossroads. [...] I tried to conjure them in my mind's eye. The waltzing ghosts of the dead meeting the afternoon passers-by'. ${ }^{19}$ Although, as Paul Magrs observes in his review of the novel, 'Glasgow is a place awash with its own perverse delights', it is also true that the city is presented in much darker terms,

\footnotetext{
${ }^{16}$ Louise Welsh, The Cutting Room (Edinburgh: Canongate, 2002), p. 196.

${ }^{17}$ Welsh, The Cutting Room, pp. 134, 167.

${ }^{18}$ Welsh, The Cutting Room, p. 249.

${ }^{19}$ Welsh, The Cutting Room, p. 190.
} 
pointing to the uneasy relationship Rilke has with the city. ${ }^{20}$ On visiting Hyndland, where McKindless used to live with his sister, his feelings reveal a strong sense of the city's Jekyll and Hyde complex: 'I hate Hyndland. You'll find its like in any large city. Green leafy suburbs, two cars, children at public school and boredom, boredom, boredom. Petty respectability up front, intricate cruelties behind closed doors' ${ }^{21}$ In hindsight, Rilke's observations foreshadow the past crimes he will set out to resolve. But similar observations about the city's lack of community ethics return when Rilke walks through the city centre:

The industrial age had given way to a white-collar revolution and the sons and daughters of shipyard toilers now tapped keyboards and answered telephones in wipe-clean sweatshops. They shuffled invisible paper and sped communications through electronic magic. [...] Elevator buildings that inspired the Chicago skyline disgorged men and women crumpled by the day, some barely a step from the door before they lit their first fag of freedom, sucking long and hard, deep inhalations that revealed their cheekbones, smoke curling from their nostrils, working for a hit. And all around me mobile phones. People talk, talk, talking to a distant party while the world marched by. ${ }^{22}$

The scene captures some important changes in the social and economic structure of the city. Glasgow's evolution from shipyard to service industry has signalled the erasure of a 'tangible' economy in favour of the simulacral commerce of 'invisible paper' and 'electronic magic'. Technological revolution also affects interpersonal social interaction: in place of face-to-face meetings, mobile phones conversations are the preferred mode of communication. In this context, the concept of 'community' becomes not only vague, but also, as Bauman argues, redundant:

\footnotetext{
${ }^{20}$ Paul Magrs, 'More tease, less strip', The Guardian, 31 August 2002

<http://www.theguardian.com/books/2002/aug/31/featuresreviews.guardianreview18> [accessed on 17 September 2014].

${ }^{21}$ Welsh, The Cutting Room, p. 2.

${ }^{22}$ Welsh, The Cutting Room, p. 65.
} 
'[C]ommunity', as a way of referring to the totality of the population inhabiting the sovereign territory of the state, sounds increasingly hollow. Interhuman bonds, once woven into a security net worthy of a large and continuous investment of time and effort, and worth the sacrifice of immediate individual interests (or what might be seen as being in an individual's interest), become increasingly frail and admitted to be temporary. ${ }^{23}$

The reasons behind the inadequacy of community to survive within the current cultural context are primarily associated with the economic and political changes dictated by capitalism and globalisation, according to Bauman:

Individual exposure to the vagaries of commodity-and-labour markets inspires and promotes division, not unity [...]. 'Society' is increasingly viewed and treated as a 'network' rather than a 'structure' (let alone a solid 'totality'): it is perceived and treated as a matrix of random connections and disconnections and of an essentially infinite volume of possible permutations. ${ }^{24}$

Behind the façade of efficient modernity and affluence, however, the sad reality of social injustice remains, as the plot of The Cutting Room unfolds as a story of systematic exploitation of the outsiders. The apparent prosperity has widened the gaps between rich and poor, both financially and morally. When Rilke gives a 'bruised boy with the face of a prophet' a coin, 'a beefy man, sweating in his grey pinstripe', grumbles '[y]ou'll only encourage him'. ${ }^{25}$

The duality of Glasgow is reflected also in the queer subtext of the novel. Although Welsh does not make this the primary theme in The Cutting Room, Rilke's sexuality, and his insider's

\footnotetext{
${ }^{23}$ Zygmunt Bauman, Liquid Times: Living in an Age of Uncertainty (Cambridge: Polity, 2007), p. 3.

${ }^{24}$ Bauman, Liquid Times, p. 3.

${ }^{25}$ Welsh, The Cutting Room, p. 66.
} 
outlook on the LGBT (lesbian, gay, bisexual, and transgender) community in Glasgow adds complexity to the novel's treatment of identity politics. Queer sexuality is another source of duality and sectarianism in Glasgow: Rilke's resistance to commitment and his casual sexual affairs, suggest a reading of his queer sexuality as anti-normative. This is also further emphasised by Rilke's observations about the transgendered community, whose secrets remain protected within the walls of the Chelsea Lounge club:

Somewhere on the journey, they may pull into a lay-by, or perhaps a deserted alleyway, remove their wig, ease out of their carefully selected frock, the satin slip, so nice to the touch, the constricting nylons, brassiere swollen with silicon mounds and bought mail order, the package collected from a PO Box hired for the purpose and opened with quick anticipation [...]. Last of all, they open the glove compartment, remove a moist wipe and, in the dim glow of the car's interior light, clean away the face they put on for a night. But while they are in the Chelsea Lounge, dressed with care, they are the girls. ${ }^{26}$

Sexual deviancy and the ambiguity of sexual desire constitute the thematic centre of The Cutting Room. While Rilke's hunt for clues to solve the mystery behind McKindless's snuff photographs puts him in contact with Glasgow's darker side, the novel deliberately erodes the boundaries between good and evil, honesty and crime, legitimate and illicit pleasures. This is particularly evident when Anne-Marie, the actress-model who once posed for McKindless, recalls the disturbing effect that his demands for sadistic shots had on her mind, when she admits to feeling 'strange', '[c]harged', 'hyper-sensitive' and ultimately 'aroused' ${ }^{27}$ Her response to McKindless's degeneracy is highly reminiscent, in its abject quality, to Henry Jekyll's description of the doctor's sensations at the time of his first transformation into his alter-ego - 'There was something strange in my sensations, something indescribably new and its very novelty, incredibly sweet', - underpinning the

\footnotetext{
${ }^{26}$ Welsh, The Cutting Room, p. 102.

${ }^{27}$ Welsh, The Cutting Room, p. 219.
} 
psychological fragmentation caused by the insurgence of desire. ${ }^{28}$ Anne-Marie's admission foreshadows the more disturbing aspects of the sexual desires and practices of the wider community of Glasgow. Her vulnerable position and alleged collusion with McKindless's games for personal gain is mirrored in the network of sex-slavery and trafficking which Anderson unveils towards the end of the novel. As well as detailing the horrific experience shared by many Eastern European women lured to Britain under the false pretences of professional career prospects, 'The Transcript of Evidence Given by Adia Kovalyova' casts a sinister light on Glasgow and its people:

We were not allowed out, but I would peer through the frosted windows and see people walking by, normal people. Then I began to think, in a world where such evil exists, are there normal people? Who were the men that used us? Did they go home and kiss their wives, cuddle their daughters, with the smell of our abuse on their fingers? $?^{29}$

Placed towards the end of the novel, the statement is yet another demonstration of the city's inherent corruption. The 'frosted windows', concealing the sins committed behind closed doors, endorse the community boundaries - leaving the 'others' out - and, simultaneously, embody the ultimate erosion of the community's moral boundaries, where the notion of normality is no longer relevant.

Set against the backdrop of a society where 'normal' people's sadistic desires result in the secretive exploitation of the 'others', and particularly the objectification of female bodies for the pleasures of the male gaze, The Cutting Room's queer subtext serves the purpose of, perhaps, showing a glimmer of hope, or at least an alternative perspective. Significantly Rilke's viewpoint establishes a counter perspective to the exploitative male gaze of pornographers such as McKindless and Trapp. That Rilke's gaze constitutes a force antithetical to that of the novel's villains is made obvious by his reaction when, at the Chelsea Lounge, he discovers a cameraman

\footnotetext{
${ }^{28}$ Robert Louis Stevenson, Strange Case of Dr Jekyll and Mr Hyde [1886] (New York: Norton, 2003), p. 50.

${ }^{29}$ Welsh, The Cutting Room, p. 282.
} 
secretly shooting a video portrait of a transvestite: 'He took people and killed them with a lens', he explains to justify his violent reaction to the event. ${ }^{30}$ Towards the end, too, Rilke, whose sexuality is still chastised in Glasgow by hypocrites such as Steenie Stevenson, feels empathy towards all the victims of sexual abuse:

And I found I wasn't crying for the girl in the photograph. I was crying for other victims, present and future. I looked once more at the images, then took out my lighter, touched flame to paper, dropped it on the earth floor, watch it curl into ash, then stamped on the embers. I sat for a moment longer, wishing there was someone to pray to, then wiped my face and went back to the bar. ${ }^{31}$

Although the ritualistic destruction of the evidence of crimes from the past may be a cathartic gesture for Rilke, the awareness remains that the city he will be returning to after a short break in Paris will continue to operate under the burden of its past crimes and, sadly, towards a less than bright future.

Burnside's The Devil's Footprints shares with The Cutting Room the exploration of the human capacity for evil and the network of dark secrets around which a community exists. At the centre of the novel is the mystery of the suicide of Moira Birnie (née Kennedy), who kills herself and two of her children by setting fire to her car. Amidst the suspicion that Moira might have been the victim of an abusive marriage, the plot revolves around the strange relationship between her surviving daughter, Hazel, and the narrator, Michael Gardiner, who used to date Moira as a youth. But the novel differs from The Cutting Room primarily in terms of its location: in place of the urban setting of Welsh's novel, Burnside's novel is set against the rural community of Coldhaven, 'a

\footnotetext{
${ }^{30}$ Welsh, The Cutting Room, p. 114.

${ }^{31}$ Welsh, The Cutting Room, p. 293.
} 
fictional fishing town on the east coast of Scotland that is quite as bad as its name'. ${ }^{32}$ Like Welsh's Glashow, however, the village community of Coldhaven is presented in Gothic terms, as a place haunted by its own mysterious past:

Long ago, in Coldhaven, a small fishing town on the east coast of Scotland, the people woke in the darkness of a mid-December morning to find, not only that their homes were buried in one of those deep, dreamlike snowfalls that only happen once or twice in a generation, but also that something strange had happened while they slept, something they could only account for in rumours and stories that, being good, church-going folk, they were ashamed to repeat, stories that grudgingly allowed for some unseen force in the world that, most of the time, they preferred to ignore. ${ }^{33}$

Significantly, the moral boundaries of the community, which on the surface would appear to be conventionally religious, are instead challenged by the persistence of the ancestors', 'superstitions and terrors', casting an uncanny shadow on the symbolic borderlines of the community, which sits in the liminal position between old and new, known and unknown, homely and unhomely. ${ }^{34}$ In its isolated position, too, Coldhaven becomes a deviant kind of place, echoing Michel Foucault's definition of 'other places' as those locations and situations which diverge from the norm; in Foucault's words, 'counter-sites ... in which the real sites ... are simultaneously represented, contested and inverted'. ${ }^{35}$ Thus Michael's 'accidental' killing of the village bully, Malcolm Kennedy, Moira's brother, becomes part of the village lore because

\footnotetext{
${ }^{32}$ Claudia Fitzherbert, 'Derangement, deaths and devils', The Telegraph, 11 March 2007

<http://www.telegraph.co.uk/culture/books/3663693/Derangement-deaths-and-devils.html> [accessed 19 September 2014].

33 John Burnside, The Devil's Footprints (London: Vintage, 2007), p. 1.

${ }^{34}$ Burnside, The Devil's Footsteps, p. 1.

${ }^{35}$ See Michel Foucault, 'Of Other Spaces', trans. by Jay Miskowiec, Diacritics, 16.1 (Spring, 1986), 22-27 (24).
} 
It was an event that happened in the shadows, back in the far corner of an old farm building, and it was an event for which nobody could be held responsible because, in that shadow place, the usual laws did not apply. ${ }^{36}$

Michael is not the only victim of bullying. When Michael's parents - 'an unsuspecting incomer with a strange accent and an American wife who was somewhat younger than himself' - choose to move to Coldhaven, their arrival marks the outsider's intrusion within the dysfunctional community of the village. ${ }^{37}$ As Michael explains,

My parents' offence, of course, was to be who they were. [...] They both wanted to belong to the place, but to my father belonging had nothing to do with blood or birth, nothing to do with community or kinship, it was all about the land and the sea, it was all about imagination, about choice. He belonged here because this was his sky, this was his light, his stretch of sea. ${ }^{38}$

Michael's parents seek a different kind of belonging, a sense of community that relates more to the place itself, its elemental beauty and topography, rather than its people. The sense of impossible belonging evoked in Burnside's novel can be read in line with Bauman's critique of the 'utopian' aspect of community; '[t]he communion of inner selves grounded in mutually encouraged selfdisclosure may be the nucleus of the love relationship', he admits, but the same template does not apply to extended kinds of communal bonds:

The tools of the I-Thou togetherness, however perfectly mastered and impeccably wielded, will prove helpless in the face of the variance, disparity and discord that separate the

\footnotetext{
${ }^{36}$ Burnside, The Devil's Footprints, p. 78.

${ }^{37}$ Burnside, The Devil's Footprints, p. 79.

${ }^{38}$ Burnside, The Devil's Footprints, p. 80-81.
} 
multitudes of those that are a potential 'Thou' from each other and keep them on a war footing: in a shooting, rather than talking mood..$^{39}$

Ostracised by the community's hostility towards them, the Gardiners' move to Whitland, on the outskirts of Coldhaven, reinforces Michael's sense of their inability to belong in the community: 'my parents didn't belong to Coldhaven. They belong to the land and the sky and the light and, maybe, they belonged to an idea that had become untenable even before I was born' ${ }^{40}$

The move also complicates the definition of home, highlighting the Gardiners' unexpressed individualisms, "each of them taking for granted that the other knew exactly what they meant by the word home' ${ }^{41}$ For Michael, however, the new house represents a different way of belonging, expressed significantly in the Gothic haunting that his new bedroom accommodates:

[It] seemed haunted by the history of that place, a history of summer warmth seeping up through the pipes and the sweet vapour of milk rising from the kitchen, a good haunting, a warm presence, like the heat that still remains in the embers of a fire long after it burns out. ${ }^{42}$

David Ratmoko notes that to 'haunt' means to 'provide with a home'. ${ }^{43}$ In its haunted status belonging both to the community's past and the Gardiners' present - the house represents the contested site of identities within the community. As Michael's father explains to his friend John:

Imagine you have been set down in a strange place, amongst strange people, people who resemble you, superficially, physically [...] - but in an odd, inconclusive way, as if there

\footnotetext{
${ }^{39}$ Bauman, Liquid Love, p. 33.

${ }^{40}$ Burnside, The Devil's Footprints, p. 89.

${ }^{41}$ Burnside, The Devil's Footprints, p. 83.

${ }^{42}$ Burnside, The Devil's Footprints, p. 90.

${ }^{43}$ David Ratmoko, On Spectrality: Fantasies of Redemption in the Western Canon (New York: Peter Lang, 2006$)$, p. 1.
} 
was nothing really to be said, other than nonsense or mild pleasantries. And, of course, you are new in their territory, you are a stranger. ${ }^{44}$

Community cannot be defined in the simple terms of kinship and shared values. A group of human beings who choose - for disparate reasons - to share the same residence does not necessarily support the foundations of community. The insider/outsider opposition is here determined not by 'foreignness' of nationality, ethnicity, or religion, but by the outsiders' different sets of knowledge, which disrupt the community: 'you are a stranger with new maps, maps they have never seen before, and they think you have come to tell them that their maps are wrong' ${ }^{45}$

The significance of partaking in the knowledge - and the secrets - of Coldhaven persists when Michael, as an adult, perceives his home as 'a sensitive membrane, a register, where every shift in the atmosphere - weather and gossip and the most subtle demographics - was brought to my awareness in real time, as it happened' ${ }^{46}$ An important channel of information is Michael's cleaner, Mrs K, who 'was born at the western end of Coldhaven, just where the devil is supposed to have emerged from the sea, that winter's morning, long ago' ${ }^{47}$ Mrs K's own peripheral position in the community makes her the receptacle of the important knowledge Michael also craves: 'like many internal exiles, [she] was an expert in gossip and it wasn't long before she became my main source of information'. ${ }^{48}$ Such gossip includes the story about the disappearance of one of the village women, Angela, who allegedly drowned herself following the birth of her abnormal child: 'a woman in Coldhaven [...] had given birth to a baby with two heads. One of the heads was perfectly formed, quite beautiful, in fact; the other was a hideous mass of noses and ears, with tiny pinpricks

\footnotetext{
${ }^{44}$ Burnside, The Devil's Footprints, p. 82.

${ }^{45}$ Burnside, The Devil's Footprints, p. 82.

${ }^{46}$ Burnside, The Devil's Footprints, p. 109.

${ }^{47}$ Burnside, The Devil's Footprints, p. 11.

${ }^{48}$ Burnside, The Devil's Footprints, p. 15.
} 
for the eyes' ${ }^{49}$ Although to begin with the narrator believes that Angela, who 'had turned into some kind of mental ghost' after the birth, ${ }^{50}$ had drowned herself, he later finds out that she is still alive. The story is indicative of the secretive knowledge that binds the community of Coldhaven together, while, simultaneously, its lack of veracity points to the bogus foundations upon which the community is based:

The whole story was shrouded in mystery, a matter of hearsay and conjecture, and nobody could agree about anything other than the plain fact that this woman, dead or alive, mad or sane, had been in love with Frank Collings, and that he was the father of her baby. ${ }^{51}$

After eloping with Hazel, only to find out that her real intention was to use him to get what she wanted, which is to run away from home and be with her boyfriend, Michael embarks on a long journey 'home' on foot. The novel's circular structure retraces the 'devil's footsteps' of the title, pointing to the uncanny repetitions that haunt the community's past and present:

The town was asleep, as it had been on that night a hundred years before, when the devil came up from the sea and walked from street to street, leaving hard, black, feral marks in the snow. [...] It should have been painfully familiar, but I was coming back to it now, as a stranger - and I was seeing it all as if for the first time. ${ }^{52}$

Michael's déjà-vu is indeed an uncanny manifestation as he experiences his return to the 'familiar' sight 'as a stranger'. Yet it is precisely the uncanniness of this experience that creates enough distance for Michael to see the community for what it is: 'The fishing was almost gone now, but it had been replaced by pleasure craft, bright, clean boats with names like Arcturus, and Khayyam and

\footnotetext{
${ }^{49}$ Burnside, The Devil's Footprints, p. 29.

${ }^{50}$ Burnside, The Devil's Footprints, p. 29?.

${ }^{51}$ Burnside, The Devil's Footprints, p. 30.

${ }^{52}$ Burnside, The Devil's Footprints, p. 198 (emphases added).
} 
Braveheart' ${ }^{53}$ Significantly, while the community appears to have moved away from its rural past and embraced a kind of global modernity (as reflected in the names of the boats), there is a sense in which its supernatural association with the devil is still an issue. This is not because Michael believes in the devil's footsteps, but because he realises there is a seamless continuity between the ordinary world of Coldhaven and the hell of the ancient belief:

But there wasn't a separate world, there was only this: the air, the sky, the snow, these strange marks, the water, the odd gust of wind finding me as I followed the tracks to where they stopped, all of a sudden, at exactly the point where my path diverged from the road. ${ }^{54}$

With no neat borders demarcating the moral boundaries of Coldhaven, the narrative suggests that the legend originates from the human awareness that we are our own devils; we are the only source of evil:

Because they were the ones who were afraid of being possessed, they were the ones who thought that the day might come when a decent citizen was going about his ordinary business, walking his fields or steering his boat through the harbour mouth, and the devil would come and touch him on the shoulder, singling him out and taking him aside so he could see and hear and smell his own true self. ${ }^{55}$

As previously seen in the intertextual structure of The Cutting Room, in engaging with the question of human duality The Devil's Footprints displays the influence of classic Scottish Gothic texts such as Hogg's Confessions of a Justified Sinner and Stevenson's Dr Jekyll and Mr Hyde, but also their twentieth-century legacy from Muriel Spark's The Ballad of Peckham Rye (1960) to James

\footnotetext{
${ }^{53}$ Burnside, The Devil's Footprints, p. 199.

${ }^{54}$ Burnside, The Devil's Footprints, p. 201.

${ }^{55}$ Burnside, The Devil's Footprints, p. 203.
} 
Robertson's The Testament of Gideon Mack (2006). With these texts, Burnside's novel shares the preoccupation with psychological fragmentation and a concern with the location of evil; as noted by Claudia Fitzherbert:

The folk tale about the devil's footprints points both to the existence of evil in the town and the difficulty of locating it. [...] And yet there is no doubt that evil has been done in Coldhaven, and will continue. We may mistake men for devils, but the footprints are real. Or are they?56

Central to Michael's narrative, then, is the tension between the narrator's solipsistic drive and his desire - and failure - to connect with other human beings. On witnessing a car accident two weeks after Moira's death, for instance, Michael recognises the track playing from one of the car stereos - Alanis Morissette's 'Mercy' - and has 'an odd sensation, to think that whoever it was who had been driving the car was someone who liked the same music I did' ${ }^{57}$ It is arguably the same desire that lets him believe that there might be a bond between himself and Hazel, even after he realises that she could not be his own daughter as previously conjectured. Yet, he feels 'connected to her, if not by blood, then by circumstance. My life was entwined with hers, one way or another' ${ }^{58}$ Significantly, what really links his fate with Hazel's is Michael's secret knowledge about the death of Malcolm, 'the uncle Hazel never got to meet'. ${ }^{59}$ In spite of these isolated episodes, Michael remains acutely aware of the solipsistic duality of the human condition, the notion that 'we are essentially alone, the idea that we never see ourselves as we seem to others, the realisation that we lie, to ourselves mostly, in a vain attempt to cheat time, to cheat death' ${ }^{60}$

\footnotetext{
${ }^{56}$ Claudia Fitzherbert, 'Derangement, deaths and devils', The Telegraph, 11 March 2007 <http://www.telegraph.co.uk/culture/books/3663693/Derangement-deaths-and-devils.html> [accessed 19 September 2014]. See also Anne Enright, 'The devil inside', The Guardian, 17 March 2007 <http://www.theguardian.com/books/2007/mar/17/featuresreviews.guardianreview17> .

${ }^{57}$ Burnside, The Devil's Footprints, p. 58.

${ }^{58}$ Burnside, The Devil's Footprints, p. 126.

${ }^{59}$ Burnside, The Devil's Footprints, p. 126.

${ }^{60}$ Burnside, The Devil's Footprints, p. 91.
} 
The tension between these opposite forces opens a split, fragments Michael's psyche, so that the insider/outsider crack within the community is also reflected in the divided self of the narrator. In a moment of lucidity, after eloping with Hazel, Michael asks himself: 'Was all this some elaborate ruse to distract myself from some deep, secret, utterly horrific perversion that I'd been nurturing for years?'. ${ }^{61}$ After the elopement his narrative disintegrates, replacing the rational balance of the first part of the story with the Gothic chaos of nightmares and hallucinations, which increasingly intrude in his narrative, pointing to his progressive psychological breakdown. Echoing Stevenson's Jekyll/Hyde, nevertheless, there is a sense in which, away from the normative constrains of his community, his alter-ego can exist in elemental communion with the wilderness:

All at once, I was aware of a chill, animal pleasure, a continuity between my own flesh and the shadows in the bushes; yet the fear, the apprehension, was still there, and I realised that these two sensations were inseparable, fear and pleasure, apprehension and the tentative joy of being there, alive. ${ }^{62}$

Such epiphanic awareness of one's own darker side, points here to the possibility of a different kind of common ground, based not on the illusion of shared values, but on the secretive awareness of shared flaws and mistakes. The notion that Moira's husband, Tom, might be the devil, rumoured to be behind Moira's suicide is in the end overtly rejected: 'It turns out he wasn't the devil after all; he was just a man', says Michael, towards the end of the story. ${ }^{63}$ This affirmation is, in turn, followed by a hint of empathy, the suggestion that a different kind of understanding might after all exist between the two men, who have in different ways been ostracised by their community: 'I feel sorry

\footnotetext{
${ }^{61}$ Burnside, The Devil's Footprints, p. 138.

${ }^{62}$ Burnside, The Devil's Footprints, p. 135.

${ }^{63}$ Burnside, The Devil's Footprints, p. 216.
} 
for him, I suppose. I never speak to him, or give out any signal that I know who he is, but there are times when I want to take him out to the point and show him the birds' ${ }^{64}$

Looking at the Scottish literary production of the last decade, it is hardly surprising that twenty-first-century Scottish fiction may have challenged Anderson's reading of 'imagined communities'. Significantly, the failure to translate the abstract notion of shared values into the incongruous, sectarian, fragmented communities which form the background of The Cutting Room and The Devil's Footprints also emerges in novels as diverse as Michel Faber's Under the Skin (2000), Zoe Strachan's Spin Cycle (2004), and Luke Sutherland's Venus as a Boy (2004). Dealing with the problematic clash between insiders and outsiders, post-devolution Scottish fiction would appear to be deeply concerned with the fixed boundaries and definitions of its communities. What these novels propose, in different ways, is to map out new kinds of communities rooted not within the contained boundaries of shared knowledge, but gravitating around the liminal spaces of secretive disjunctures. Reworking Freud's theory of the uncanny, Julia Kristeva has argued for an ethical understanding of the coalescence of familiar and unfamiliar within our selves and our communities:

With Freud indeed, foreignness, an uncanny one, creeps into the tranquillity of reason itself, and without being restricted to madness, beauty, or faith anymore than to ethnicity or race, irrigates our very speaking-being, estranged by other logics, including the heterogeneity of biology... Henceforth, we know that we are foreigners to ourselves, and it is with the help of that sole support that we can attempt to live with others. ${ }^{65}$

It is precisely in line with these principles that the novels analysed in this chapter reflect on the paradoxes of the communal values and shared geographies we associate with the narrative of community. Both novels expose communities as, on the one hand, the ambiguous sites of

\footnotetext{
${ }^{64}$ Burnside, The Devil's Footprints, p. 217.

${ }^{65}$ Julia Kristeva, Strangers to Ourselves (London: Harvester Wheatsheaf, 1991), p. 170.
} 
familiarity, comfort, and understanding, and on the other, strangeness, disturbance, and conflict. Haunting the narratives, therefore, is an uncanny community spirit - a web of secretive knowledge around which the community revolves. Perhaps the most unsettling secret, implied in both narratives, points to the inherently divided structure of the human self as that which is responsible for the predicament of uncanny communities. In other words, behind these uncanny communities are uncanny individual selves. In Kristeva's words: 'Uncanny, foreignness is within us: we are our own foreigners, we are divided'. ${ }^{66}$

\section{Bibliography}

Bauman, Zygmunt, Liquid Love: On the Frailty of Human Love (Cambridge: Polity, 2003).

Liquid Times: Living in an Age of Uncertainty (Cambridge: Polity, 2007).

Anderson, Benedict, Imagined Communities: Reflections on the Origin and Spread of Nationalism (London and New York: Verso, 1991).

Bennett, Andrew and Nicholas Royle, An Introduction to Literature, Criticism and Theory (Harlow: Pearson, 2004), p. 34.

Bhabha, Homi K., 'Introduction: Narrating the Nation', in Nation and Narration ed. by Homi K. Bhabha (London: Routledge, 1990).

Burnside, John, The Devil's Footprints (London: Vintage, 2007).

Cohen, A. P., The Symbolic Construction of Community (London and New York: Routledge, 1985).

\footnotetext{
${ }^{66}$ Kristeva, Strangers to Ourselves, p. 181.
} 
Delanty, Gerard, Community (London and New York: Routledge, 2003).

Fitzherbert, Claudia, 'Derangement, deaths and devils', The Telegraph, 11 March 2007 <http://www.telegraph.co.uk/culture/books/3663693/Derangement-deaths-and-devils.html> [accessed 19 September 2014].

Foucault, Michel, 'Of Other Spaces', trans. by Jay Miskowiec, Diacritics, 16.1 (Spring, 1986), 2227.

Freud, Sigmund, The Uncanny [1919], ed. by Hugh Haughton, trans. by David McLintock (London: Penguin, 2003).

Kristeva, Julia, Strangers to Ourselves (London: Harvester Wheatsheaf, 1991).

McDowell Lesley, 'The Cutting Room by Louise Welsh: The literary beauty of a Glaswegian beast', The Independent, 9 August $2002<\mathrm{http}: / / \mathrm{www}$.independent.co.uk/artsentertainment/books/reviews/the-cutting-room-by-louise-welsh-639353.html> [accessed 17 September 2014].

Magrs, Paul, 'More tease, less strip', The Guardian, 31 August 2002

<http://www.theguardian.com/books/2002/aug/31/featuresreviews.guardianreview18> [accessed on 17 September 2014].

Miller, S. M., Recapitalizing America: Alternatives to the Corporate Distortion of National Policy (Boston: Routledge and Kegan Paul, 1981). 
Punter, David, 'The Uncanny', in The Routledge Companion to Gothic, ed. by Catherine Spooner and Emma McEvoy (London and New York: Routledge, 2007), pp. 129-136.

Ratmoko, David, On Spectrality: Fantasies of Redemption in the Western Canon (New York: Peter Lang, 2006).

Rutherford, Jonathan, 'A Place Called Home: Identity and the Cultural Politics of Difference', in Identity: Community, Culture, Difference, ed. by Jonathan Rutherford (London: Lawrence \& Wishart, 1990), pp. 9-27.

Stevenson, Robert Louis, Strange Case of Dr Jekyll and Mr Hyde (New York: Norton, 2003).

Welsh, Louise, The Cutting Room (Edinburgh: Canongate, 2002). 